\title{
Ultrasound-guided single-injection femoral nerve block provides effective analgesia after total knee arthroplasty up to 48 hours
}

\author{
Ultrasonografi eşliğinde yapılan tek doz femoral sinir bloğu \\ diz artroplasti sonrası 48 saat'e kadar etkin analjezi sağlar
}

Levent ŞAHIN, ${ }^{1}$ Halil Fatih KORKMAZ, ${ }^{2}$ Mehrican ŞAHIN, ${ }^{3}$ Güneri ATALAN ${ }^{4}$

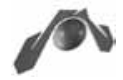

\begin{abstract}
Summary
Objectives: The purpose of this study is to evaluate the effects of ultrasound (US) guided single-injection femoral nerve block (FNB) spinal anesthesia on pain control, morphine consumption, adverse effects, and patient satisfaction during the postoperative 48-hour period in patients undergoing total knee arthroplasty (TKA).

Methods: One hundred four ASA physical status I-III patients undergoing single TKA for degenerative joint disease were enrolled in this clinical study. Patients were randomly distributed into two groups: US-guided single-injection FNB with 40 $\mathrm{ml}$ of $0.5 \%$ bupivacaine and $1: 200,000$ epinephrine was administered to Group $\mathrm{F}(\mathrm{n}=51)$ patients. Preservative-free saline was injected in Group P $(n=53)$ patients using the same method as Group F. Pain scores, morphine consumption, incidences of adverse events, and patient satisfaction were assessed over the course of 48 hours.

Results: Group F used significantly less morphine compared with Group P (18.7 mg vs. $39.6 \mathrm{mg}$ ) during the first 48 hours after surgery $(\mathrm{p}<0.001)$. When compared with group $\mathrm{P}$, the VRS scores both at rest and during movement were significantly lower in Group F at 4, 8, 12, 24, and 48 hours after TKA (for all comparisons $\mathrm{p}<0.001$ ). In addition, patient satisfaction was better in Group F than Group P.

Conclusion: This study suggests that a US-guided single-injection femoral nerve block following TKA improves patient satisfaction and reduces consumption of morphine during the first 48 hours.
\end{abstract}

Key words: Analgesia; bupivacaine; femoral nerve block; knee arthroplasty; ultrasound.

\begin{abstract}
Özet
Amaç: Bu çalışmanın amacı spinal anestezi ile total diz artroplastisi (TDA) yapılan hastalarda postoperatif 48 saatlik periyotta ultrason (US) kılavuzluğunda tek doz femoral sinir bloğunun (FSB) ağrı kontrolü, morfin tüketimi, olumsuz etkiler ve hasta memnuniyeti üzerine etkilerini değerlendirmek.

Gereç ve Yöntem: Dejeneratif eklem hastaliğı nedeniyle tek tarafl TDA uygulanacak, ASA fiziksel durumu I-III olan 104 basta bu çalışmaya dabil edildi. Hastalar rastgele iki guruba ayrildı: Grup F (n=51) bastalara US kılavuzluğunda FSB'da 1: 200,000 epinefrin ilave edilmiş $40 \mathrm{ml} \% 0.5$ bupivakain, Grup $P(n=53)$ bastalara ayn metod ile koruyucu serbest salin enjeksiyonu yapıldı. Ağrı skorları, morfin tüketimi, olumsuz olaylar ve hasta memnuniyeti 48 saat boyunca değerlendirildi.

Bulgular: Cerrabi sonrası ilk 48 boyunca Grup F'de Grup P ile kıyaslandığında anlamlı olarak daba az morfin tüketilmiştir (18.7 $m g$ ile 39.6 mg, $p<0.001$ ). Dört, 8, 12, 24 ve 48. saatlerde Grup P ile karşılaştırıldı̆̆ında Grup F'de hem istirahette bem de hareketle VRS skorları anlamlı olarak daha düşüktür (tüm karşılaştırmalar için p<0.001). Ayrıca basta memnuniyeti Grup F'de Grup P'den daha iyiydi.

Sonuçः Bu çalışma US kılavuzluğunda tek doz femoral sinir bloğunun TDA'ni takiben ilk 48 saatte basta memnuniyetini artırdığı ve morfin tüketimini azalttığını göstermiştir.
\end{abstract}

Anahtar sözcükler: Analjezi; bupivakain; femoral sinir bloğu; diz artroplastisi; ultrason.

'Department of Anesthesiology, Gaziantep University Faculty of Medicine, Gaziantep, Turkey;
2Department of Anesthesiology, Kütahya State Hospital, Kütahya, Turkey;
${ }^{3}$ Department of Anesthesiology, 75. Yıl State Hospital, Gaziantep, Turkey;
${ }^{4}$ Department of Anesthesiology, Elazığ State Hospital, Elazığ, Turkey
${ }^{1}$ Gaziantep Üniversitesi Tıp Fakültesi Hastanesi, Anesteziyoloji Anabilim Dalı, Gaziantep;
${ }^{2}$ Kütahya Devlet Hastanesi, Anesteziyoloji Bölümü, Kütahya;
${ }^{3} 75$. Yıl Devlet Hastanesi, Anesteziyoloji Bölümü, Gaziantep;
${ }^{4}$ Elazığ Devlet Hastanesi, Anesteziyoloji Bölümü, Elazığ
Submitted (Başvuru tarihi) 09.12.2011 Accepted after revision (Düzeltme sonrası kabul tarihi) 26.10.2013

Correspondence (IIletişim): Dr. Levent Şahin. Gaziantep Üniversitesi Tıp Fakültesi Hastanesi Anesteziyoloji ve Reanimasyon Kliniği Ameliyathane, Gaziantep, Turkey.

Tel: +90 - 342 - 3606060 e-mail (e-posta): drlsahin@hotmail.com 


\section{Introduction}

Pain control after total knee arthroplasty (TKA) is an important factor in optimal postoperative knee rehabilitation. ${ }^{[1]}$ For analgesia after TKA, singleinjection femoral nerve block (SFNB) has been widely studied and found to significantly improve pain control and functional outcomes such as knee flexion and length of hospital stay. ${ }^{[2]}$ The analgesia duration of SFNB applied without US has been found to be more or less than 24 hours. ${ }^{[3-5]}$ Because it improves localization of the nerve and visualization of the spread of the LA solution, US-guided SFNB results in improved blocking characteristics such as faster onset and longer duration. ${ }^{[6,7]}$ Studies about US-guided SFNB with high-volume LA and follow-up over 48 hours are rare in the literature. We wonder whether or not SFNB with high volume LA can provide postoperative analgesia over 48 hours.

The present prospective, randomized, double-blind, and placebo-controlled study was designed to investigate the efficacy of US-guided SFNB using $40 \mathrm{ml}$ volume LA in the management of pain after TKA under spinal anesthesia over the postoperative 48 hours.

\section{Materials and Methods}

This prospective, randomized, double-blind, and placebo-controlled clinical study was reviewed and approved by the Dumlupinar University, Faculty of Medicine, Ethics Committee. After obtaining written informed consent, 104 patients with American Society of Anesthesiologists Physical Status Scores (ASA-PS) I-III undergoing single TKA for degenerative joint disease were enrolled in the clinical study. Patients were excluded if they were $<40$ or $>80$ years of age, pregnant, or had a history of the following: chronic obstructive lung disease, allergy to a study drug, chronic pain syndrome unrelated to their knee pathology, chronic opioid use, contraindications to regional anesthesia, or inability to understand verbal rating score (VRS) for pain $(0=$ no pain; $10=$ worst pain imaginable) or patient-controlled analgesia (PCA) device usage. Once enrolled, patients were removed from the study if they experienced a failed femoral nerve block or spinal anesthesia. During the preoperative visit, patients were briefed on the use of the PCA device (Life Care Abbott PCA 4100 pump, USA).
Patients were randomized into one of two groups on the day of surgery, using computer-generated assignment. Premedication consisted of 1-2 mg of intravenous midazolam for all patients at the discretion of the anesthesia team. After placement of standard ASA monitors and supplemental oxygen, both groups received $15 \mathrm{mg}$ of intrathecal hyperbaric bupivacaine (Marcaine spinal heavy 0.5\% AstraZeneca, Lüleburgaz, Turkey) as the surgical anesthetic agent. Intrathecal injections were performed, with the patient in a sitting or lateral position, through the L3-4 or L4-5 interspace. Intraoperative sedation was achieved by intravenous midazolam titrated at the discretion of the primary anesthesiologist team. TKA was performed by one of two surgeons using the same surgical technique and implants. Intraoperative data that was collected includes tourniquet time and duration of surgery, defined as the time elapsed from skin incision to bandage application.

In the FNB group (Group F, $\mathrm{n}=51$ ) patients, a single shot of FNB was performed in the recovery room when the spinal block height was regressed to T12. The other group (Group P, $\mathrm{n}=53$ ) received a placebo injection with normal saline of an equal volume. Under sterile conditions, the femoral artery and nerve were visualized using a high-resolution ultrasound device (Mindray DC-6 Expert Diagnostic Ultrasound System linear array transducer 10L4, China) at the inguinal crease. Then, a 21-gauge insulated needle (PlexoLong Nanoline Pajunk, Geisingen, Germany) was advanced under US. The final position of the needle was verified with the use of a nerve stimulator (Stimuplex HNS 12, B Braun, Germany). The end-point used for injection was an ipsilateral quadriceps contraction at $<0.5 \mathrm{~mA}$. At that point, $40 \mathrm{ml}$ of $0.5 \%$ bupivacaine with $1: 200,000$ epinephrine was injected slowly after negative aspiration. The injection of LA was visualized with US. Each patient, regardless of group assignment, had a dry sterile dressing placed on his or her groin.

Postoperatively, all patients received a PCA pump programmed to deliver $2 \mathrm{mg}$ intravenous morphine on demand with a lockout time of ten minutes for the first 48 hours after operation. During the hospital stay, all patients received $600 \mathrm{mg}$ oral ibuprofen three times a day, beginning in the afternoon on the day of surgery. Postoperative antiemetic medication was standardized: intravenous metoclopramide (10 
Table 1. Demographic data and preoperative parameters

\begin{tabular}{lcc}
\hline & Group P (n=53) & Group F (n=51) \\
\hline Age (yr) & $59 \pm 6.8$ & $61 \pm 5.9$ \\
Sex (F/M) & $37 / 16$ & $34 / 19$ \\
Weight (kg) & $77 \pm 14.6$ & $75 \pm 12.9$ \\
ASA-PS II & 28 & 24 \\
ASA-PS III & 25 & 27 \\
Tourniquet time (min) & $69 \pm 14.5$ & $74 \pm 12.7$ \\
Operation time (min) & $98 \pm 19.4$ & $104 \pm 22.3$ \\
Spinal injection-FNB interval & $166 \pm 33.6$ & $158 \pm 25.8$ \\
\hline Values expressed as mean+SD or numbers (n) Group P: sham block: Group F: femoral nerve block (FNB).
\end{tabular}

$\mathrm{mg}$ ) was given as required, and ondansetron $(8 \mathrm{mg})$ was administered if nausea persisted 30 minutes after metoclopramide.

Postoperative data was collected by independent observers blinded to the groups. Time 0 was defined as when FNB was applied. The following measurements were recorded: VRS at rest and movement as primary aim; cumulative morphine consumption; incidence of adverse events (presence of nausea or vomiting, pruritus, dizziness, and injection site infection/hematoma); and patient satisfaction as secondary aims were also recorded at 1, 4, 8, 12, 24, and 48 hours, postoperatively. Prior to discharge, the patients were asked to assess their satisfaction with their anesthetic experience on a four-point categorical scale ( 1 =outstanding; $2=$ very good; $3=$ satisfactory; $4=$ unsatisfactory).

After the power analysis of the incidence of postop- erative rest pain scores at 48 hours, total sample size was 86 , and effect size was 0.72 (alpha $=0.05$, actual power $=0.95$, delta $=3.32$ ). The independent sample t-test for parametric data, Wilcoxon test for VRS, and Mann-Whitney U-test were used for patient satisfaction. Statistical significance was reported when the $p$ value was $<0.05$. The results of the study were evaluated using the SPSS statistical analysis package (Statistical Package for Social Sciences Release 15.0 for Windows).

\section{Results}

Of the 110 patients who underwent elective TKA surgery, six patients experienced inefficient spinal anesthesia and were excluded from the study. Of the remaining 104 subjects, 53 patients were included in the placebo group and 51 patients in the FNB group. There was no statistically significant difference in patients' age, weight, gender, ASA classifica-

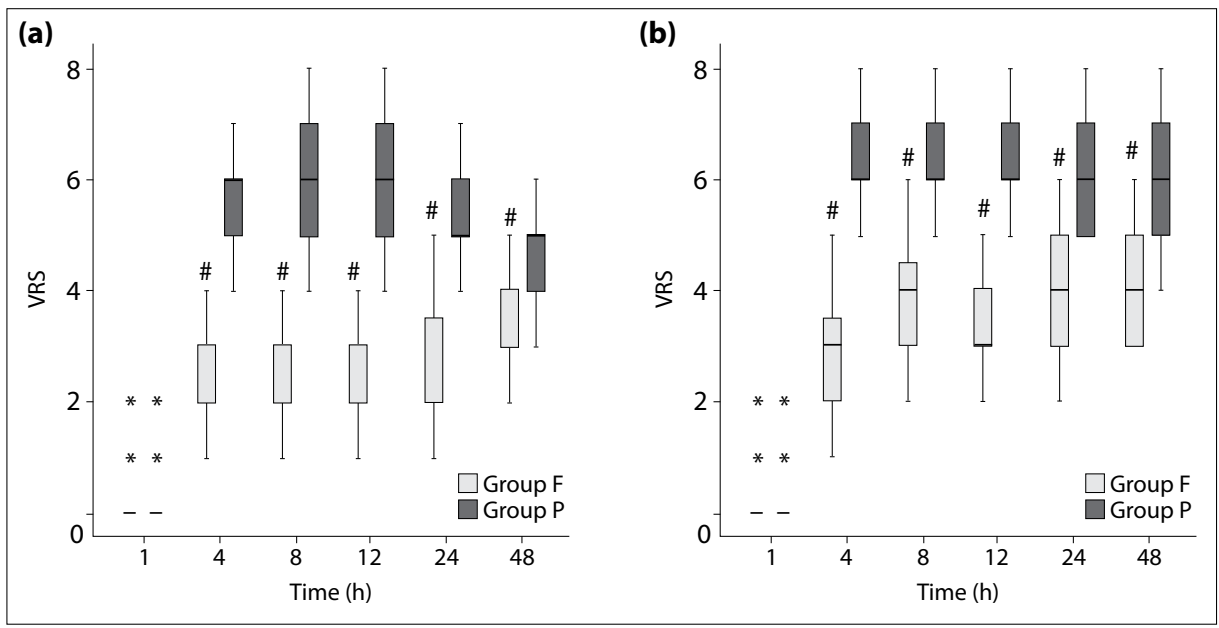

Figure 1. (a) Verbal rating score (VRS) for pain at rest in both groups. (b) Verbal rating score (VRS) for pain at movement in both groups. Values expressed as median (range). Group P: sham block; Group F: femoral nerve block; \# $\mathrm{p}<0.001$ between groups. 


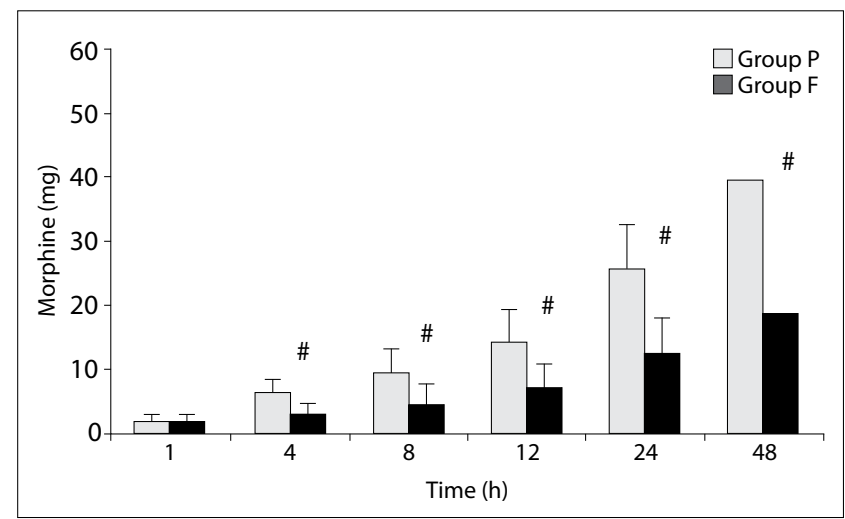

Figure 2. Cumulative morphine use for sham block compared with femoral nerve block. Values expressed as mean \pm SD. Group $P$ : sham block; Group F: femoral nerve block; $\# p<0.001$ between groups.

tion, tourniquet time, duration of operation, and times from spinal injection to the FNB procedure between the two groups (Table 1).

VRS over 48 hours at rest and during movement as primary outcomes are presented in Figures 1a and $b$. Except for VRS at rest and movement at the first hour, there were significant differences between VRS between the groups at all times, both at rest and during movement (for all $\mathrm{p}<0.001$ ). The amount of cumulative morphine consumption from the secondary outcomes was significantly lower in Group F compared to Group P at all times, except for the first hour (Figure 2). Group P used more morphine compared to Group F (25.6 \pm 7.2 vs. $12.4 \pm 5.3 \mathrm{mg}$ $[\mathrm{p}<0.001], 39.6 \pm 11.2$ vs. $18.7 \pm 9.6 \mathrm{mg}[\mathrm{p}<0.001]$ respectively) during the first 24 and 48 hours after surgery. A significant difference was found between the satisfactory levels of Group F and Group P (Table 2) as other secondary outcomes. Adverse symptoms related to analgesic treatment such as nausea, vomiting, pruritus, and dizziness were not found to be statistically different between the two groups ( $\mathrm{Ta}$ ble 3). There were no complications of prolonged anesthesia, infectious complications, or damage to the femoral nerve from the FNB procedure.

\section{Discussion}

The most important finding of the present study, US-guided SFNB with $40 \mathrm{ml}$ of $0.5 \%$ bupivacaine compared to the placebo provides lower VRS both at rest and during movement, and significantly less morphine consumption during the first 48 hours following TKA.

FNBs, both continuous and single-injection techniques, are effective strategies for providing postoperative analgesia, opiate-sparing effect, and fewer associated adverse effects after TKA. ${ }^{[8-11]}$ In addition, femoral nerve blocks can reduce the reflex of the quadriceps muscle, thus reducing pain and muscle spasms ${ }^{[12]}$ which may provide a positive contribution in facilitating physical therapy and early ambulation, as well as reduce the length of hospitalization. ${ }^{[11,13]}$ In this study, longer analgesia time may have resulted from the injection of high-volume LA

Table 2. Patient satisfaction

\begin{tabular}{lccc}
\hline & Group P (n=53) & Group F $(\mathbf{n = 5 1 )}$ & $\boldsymbol{p}$ \\
\hline Patient satisfaction & $4(1-4)$ & $2(1-4)$ & $<0.01$ \\
\hline
\end{tabular}

Values expressed as median (range). Group P: sham block; Group F: femoral nerve block.

Table 3. Adverse effects related to analgesic treatment

\begin{tabular}{|c|c|c|c|c|c|}
\hline \multirow[t]{2}{*}{ Adverse effects } & \multicolumn{2}{|c|}{ Group $P(n=53)$} & \multicolumn{2}{|c|}{ Group F $(n=51)$} & \multirow[t]{2}{*}{$p$} \\
\hline & $\mathbf{n}$ & $\%$ & $\mathbf{n}$ & $\%$ & \\
\hline Nausea & 13 & 25 & 9 & 18 & NS \\
\hline Vomiting & 10 & 19 & 6 & 12 & NS \\
\hline Pruritus & 7 & 13 & 4 & 8 & NS \\
\hline Dizziness & 10 & 19 & 7 & 14 & NS \\
\hline
\end{tabular}

Values expressed as number (percent). Group P: sham block; Group F: femoral nerve block; NS: not significant $(p>0.05)$. 
into the right place, due to direct observation of its spread with US guidance. Thus, reduced complications and increased success rates can be provided with the same LA volume by using US. ${ }^{[6,7,14]}$ As is well known, reduced LA volume is related to a reduced incidence of LA toxicity. However, highvolume LA was used in this study to verify the hypothesis that higher volume results in longer analgesia. In spite of the high volume, toxicity was not observed. This is likely due to the correct spread of LA under US and the addition of epinephrine to LA in order to slow the absorption of LA.

LA volume for SFNB is an effective factor for analgesia duration. Kardash et al. ${ }^{[15]}$ reported that the analgesic effect of SFNB with $20 \mathrm{ml}$ LA was less than 24 hours. It can be explained by the fact that low-volume LA without US was used. However, Ozen et al. ${ }^{[16]}$ and Wang et al., ${ }^{[2]}$ who used the highvolume LA, as in this study, found that analgesia time was 10 and 24 hours, respectively. The shorter analgesia duration, in spite of the same volume, may be because US was not used. If US is not used, one can never be sure that the entire anesthetic volume was applied to the right place. In another study, the authors compared SFNB with intrathecal morphine use, using $40 \mathrm{ml}$ LA volume, as in this study. However, they only followed their patients for 24 hours. ${ }^{[17]}$ Therefore, this present controlled study is a rare study in the literature because of the 48-hour follow-up after US-guided SFNB with high-volume LA. Only one other controlled study reported that the analgesic benefits may extend through 48 hours. ${ }^{[18]}$ Although they used $0.25 \%$ bupivacaine, their results confirm ours.

A recently published meta-analysis related to FNB showed that SFNB reduces PCA morphine consumption and pain scores at 24 hours and 48 hours, compared with PCA alone in an evaluation of ten studies. ${ }^{[19]}$

As a limitation we did not compare the single FNB to a continuous one, but considering that continuous FNB is a sophisticated technique with catheterrelated complications such as infection, ${ }^{[20]}$ we believe that US-guided SFNB is a simpler, lower-cost, and effective alternative to femoral catheterization. Although the present study has clinical importance, the findings could be considered preliminary data, and the results, especially the lower frequency of adverse effects, should be confirmed by larger studies for adequate validation. In addition, further studies must be designed to determine the optimal volume and concentration of US-guided FNB.

In conclusion, a US-guided SFNB with $40 \mathrm{ml}$ volume LA following TKA is an effective and safe method for controlling pain. It decreases morphine consumption and may be a major component in pain management during the first 48 hours.

\section{Conflict-of-interest issues regarding the author- ship or article: None declared.}

\section{Peer-rewiew: Externally peer-reviewed.}

\section{References}

1. Mahoney OM, Noble PC, Davidson J, Tullos HS. The effect of continuous epidural analgesia on postoperative pain, rehabilitation, and duration of hospitalization in total knee arthroplasty. Clin Orthop Relat Res 1990;(260):30-7.

2. Wang $H$, Boctor $B$, Verner J. The effect of single-injection femoral nerve block on rehabilitation and length of hospital stay after total knee replacement. Reg Anesth Pain Med 2002;27(2):139-44. CrossRef

3. de Lima E Souza R, Correa $\mathrm{CH}$, Henriques MD, de Oliveira $C B$, Nunes TA, Gomez RS. Single-injection femoral nerve block with $0.25 \%$ ropivacaine or $0.25 \%$ bupivacaine for postoperative analgesia after total knee replacement or anterior cruciate ligament reconstruction. J Clin Anesth 2008;20(7):521-7.

4. Duarte VM, Fallis WM, Slonowsky D, Kwarteng K, Yeung CK. Effectiveness of femoral nerve blockade for pain control after total knee arthroplasty. J Perianesth Nurs 2006;21(5):3116. CrossRef

5. Hunt KJ, Bourne MH, Mariani EM. Single-injection femoral and sciatic nerve blocks for pain control after total knee arthroplasty. J Arthroplasty 2009;24(4):533-8. CrossRef

6. Capdevila X, Biboulet $P$, Morau D, Mannion S, Choquet O. How and why to use ultrasound for regional blockade. Acta Anaesthesiol Belg 2008;59(3):147-54.

7. Abrahams MS, Aziz MF, Fu RF, Horn JL. Ultrasound guidance compared with electrical neurostimulation for peripheral nerve block: a systematic review and meta-analysis of randomized controlled trials. Br J Anaesth 2009;102(3):408-17.

8. Barrington MJ, Olive D, Low K, Scott DA, Brittain J, Choong P. Continuous femoral nerve blockade or epidural analgesia after total knee replacement: a prospective randomized controlled trial. Anesth Analg 2005;101(6):1824-9. CrossRef

9. Sundarathiti $P$, Ruananukul $N$, Channum T, Kitkunasathean C, Mantay A, Thammasakulsiri J, et al. A comparison of continuous femoral nerve block (CFNB) and continuous epidural infusion (CEI) in postoperative analgesia and knee rehabilitation after total knee arthroplasty (TKA). J Med Assoc Thai 2009;92(3):328-34.

10. Hogan MV, Grant RE, Lee L Jr. Analgesia for total hip and 
knee arthroplasty: a review of lumbar plexus, femoral, and sciatic nerve blocks. Am J Orthop (Belle Mead NJ)2009;38(8):E129-33.

11. Allen HW, Liu SS, Ware PD, Nairn CS, Owens BD. Peripheral nerve blocks improve analgesia after total knee replacement surgery. Anesth Analg 1998;87(1):93-7. CrossRef

12. Serpell MG, Millar FA, Thomson MF. Comparison of lumbar plexus block versus conventional opioid analgesia after total knee replacement. Anaesthesia 1991;46(4):275-7. CrossRef

13. Capdevila X, Barthelet $Y$, Biboulet $P$, Ryckwaert $Y$, Rubenovitch J, d'Athis F. Effects of perioperative analgesic technique on the surgical outcome and duration of rehabilitation after major knee surgery. Anesthesiology 1999;91(1):8-15. CrossRef

14. Marhofer $P$, Schrögendorfer $K$, Koinig $H$, Kapral S, Weinstabl C, Mayer N. Ultrasonographic guidance improves sensory block and onset time of three-in-one blocks. Anesth Analg 1997;85(4):854-7. CrossRef

15. Kardash K, Hickey D, Tessler MJ, Payne S, Zukor D, Velly AM. Obturator versus femoral nerve block for analgesia after total knee arthroplasty. Anesth Analg 2007;105(3):853-8. CrossRef

16. Ozen M, Inan N, Tümer F, Uyar A, Baltaci B. The effect of 3-in-
1 femoral nerve block with ropivacaine $0.375 \%$ on postoperative morphine consumption in elderly patients after total knee replacement surgery. Agri 2006;18(4):44-50.

17. Sites BD, Beach M, Gallagher JD, Jarrett RA, Sparks MB, Lundberg $C J$. A single injection ultrasound-assisted femoral nerve block provides side effect-sparing analgesia when compared with intrathecal morphine in patients undergoing total knee arthroplasty. Anesth Analg 2004;99(5):1539-43. CrossRef

18. Ng HP, Cheong KF, Lim A, Lim J, Puhaindran ME. Intraoperative single-shot " 3 -in-1" femoral nerve block with ropivacaine $0.25 \%$, ropivacaine $0.5 \%$ or bupivacaine $0.25 \%$ provides comparable 48-hr analgesia after unilateral total knee replacement. Can J Anaesth 2001;48(11):1102-8. CrossRef

19. Paul JE, Arya A, Hurlburt L, Cheng J, Thabane L, Tidy A, et al. Femoral nerve block improves analgesia outcomes after total knee arthroplasty: a meta-analysis of randomized controlled trials. Anesthesiology 2010;113(5):1144-62. CrossRef

20. Cuvillon P, Ripart J, Lalourcey L, Veyrat E, L'Hermite J, Boisson $C$, et al. The continuous femoral nerve block catheter for postoperative analgesia: bacterial colonization, infectious rate and adverse effects. Anesth Analg 2001;93(4):1045-9. 